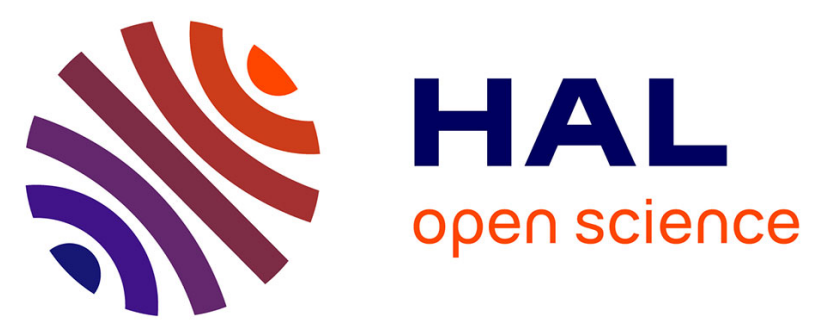

\title{
Major postglacial summer temperature changes in the central coniferous boreal forest of Quebec (Canada) inferred using chironomid assemblages
}

Lisa Bajolle, Isabelle Larocque-Tobler, Emmanuel Gandouin, Martin Lavoie, Yves Bergeron, Adam A Ali

\section{To cite this version:}

Lisa Bajolle, Isabelle Larocque-Tobler, Emmanuel Gandouin, Martin Lavoie, Yves Bergeron, et al.. Major postglacial summer temperature changes in the central coniferous boreal forest of Quebec (Canada) inferred using chironomid assemblages. Journal of Quaternary Science, 2018, 33 (4), pp.409 - 420. 10.1002/jqs.3022 . hal-01890700

\section{HAL Id: hal-01890700 \\ https://hal-amu.archives-ouvertes.fr/hal-01890700}

Submitted on 8 Oct 2018

HAL is a multi-disciplinary open access archive for the deposit and dissemination of scientific research documents, whether they are published or not. The documents may come from teaching and research institutions in France or abroad, or from public or private research centers.
L'archive ouverte pluridisciplinaire HAL, est destinée au dépôt et à la diffusion de documents scientifiques de niveau recherche, publiés ou non, émanant des établissements d'enseignement et de recherche français ou étrangers, des laboratoires publics ou privés. 


\title{
Major postglacial summer temperature changes in the central coniferous boreal forest of Quebec (Canada) inferred using chironomid assemblages
}

\author{
LISA BAJOLLE, ${ }^{1,2 *}$ ISABELLE LAROCQUE-TOBLER, ${ }^{3}$ EMMANUEL GANDOUIN, ${ }^{4}$ MARTIN LAVOIE, ${ }^{5}$ \\ YVES BERGERON ${ }^{1,6}$ and ADAM A. ALI ${ }^{1,2}$ \\ ${ }^{1}$ Institut de Recherche sur la forêt, Université du Québec en Abitibi-Témiscamingue, Rouyn-Noranda, QC, Canada \\ ${ }^{2}$ Institut des Sciences de l'Évolution-Montpellier, UMR 5554, Université de Montpellier CNRS-IRD-EPHE, Montpellier, France \\ ${ }^{3}$ The L.A.K.E.S Institute, Lyss, Switzerland \\ ${ }^{4}$ Aix Marseille Univ, Univ Avignon, CNRS, IRD, IMBE, Aix-en-Provence, France \\ ${ }^{5}$ Département de géographie and Centre d'études nordiques, Université Laval, Québec, QC, Canada \\ ${ }^{6}$ Centre d'Étude de la Forêt, Université du Québec à Montréal, Montréal, QC, Canada
}

\begin{abstract}
Chironomid head capsules preserved in lake sediments were used to reconstruct 8200 years of summer temperatures in the boreal forest of north-eastern Canada. Two training sets were used derived from Canadian and Eastern Canadian transfer functions. Both models reconstructed similar climate patterns, but the Canadian model provided temperatures generally $2-3{ }^{\circ} \mathrm{C}$ lower than the Eastern Canadian model. Three main thermal changes inferred by chironomids were: (i) the Holocene Thermal Maximum, which occurred between 8 and $5 \mathrm{k}$ cal a BP, with temperatures generally higher than today's, maximum temperatures between 8 and $6.5 \mathrm{k}$ cal a BP, and an average of $+0.9^{\circ} \mathrm{C}$; (ii) the Medieval Climate Anomaly around $1.1-1.2 \mathrm{k}$ cal a BP with an amplitude of $+0.7^{\circ} \mathrm{C}$; and (iii) a colder period reconstructed between the 14th and 19th centuries, corresponding to the Little Ice Age, with summer temperatures on average $-0.5{ }^{\circ} \mathrm{C}$ lower than the climate normal. For each of these three climatic events, the timing and the amplitude of changes were similar with other published regional, North American and Northern Hemisphere records. Copyright (C) 2018 John Wiley \& Sons, Ltd.
\end{abstract}

KEYWORDS: Chironomidae; Holocene Thermal Maximum; Little Ice Age; Medieval Climate Anomaly; transfer functions.

\section{Introduction}

Paleoclimatic records covering the Northern Hemisphere are still too sparse to obtain a precise representation of past climate change (Naulier et al., 2015). For example, the amplitude and duration of the Medieval Climate Anomaly (MCA) remain of debate (Mann and Jones, 2003; Viau et al., 2006; Esper and Frank, 2009). The MCA has been characterized by notably higher temperatures between $\sim 950$ and 1200 AD over a large part of the North Atlantic, in southern Greenland, the Eurasian Arctic and parts of North America (Lamb, 1965). However, its amplitude, location and extent are still undefined for most parts of the Northern Hemisphere. Another period of concern in North America is the Holocene Thermal Maximum (HTM). In Canada, the HTM seems to have varied between shorter (7-5k cal a BP) and longer (10$3 \mathrm{k}$ cal a BP) durations and its amplitude was different depending on the location (Renssen et al., 2012). Thus, it is impossible to strictly define these periods of interest in North America since quantitative long-term data are missing in several regions.

Climate models need quantitative data to be able to accurately predict future ecosystem functioning. Proxyclimate-based reconstructions must be realistic and reliable, and if possible they should be validated by independent climate reconstructions from other proxies (Birks, 2003). Climate (temperature, precipitation) records from biological proxies such as pollen and chironomids preserved in lacustrine deposits allow adequate long-term information to

${ }^{*}$ Correspondence: Lisa Bajolle, as above.

E-mail: lisa.bajolle@uqat.ca; bajolle.lisa@gmail.com quantify past climatic variability (Larocque-Tobler et al., 2012; Heiri et al., 2015).

Chironomids (Insecta: Diptera: Chironomidae) have been shown to generate high-resolution independent air temperature records due to their capacity to respond rapidly to climatic fluctuation with their short generation time and the ability of winged adults to move readily from site to site (Walker and Mathewes, 1987; Larocque-Tobler et al., 2015). The head capsule of the chironomid larvae is made of chitin, a substance resistant to degradation, thus allowing the larval exoskeletons to be preserved for thousands of years. The distribution of chironomids has been shown to be influenced by air/water temperatures (Walker and Mathewes, 1987). In addition, with the help of transfer functions (Birks and Birks, 1998), they can record low-amplitude summer temperature changes (Brooks, 2006; Larocque-Tobler et al., 2015). For example, when comparing instrumental data to chironomidinferred temperatures, the differences were on average $0.75^{\circ} \mathrm{C}$ in a Polish lake (Larocque-Tobler et al., 2015) and $0.65^{\circ} \mathrm{C}$ in a Swiss lake (Larocque et al., 2009).

In the boreal region of north-eastern Canada, Holocene quantitative reconstructions of past climate change are mostly based on pollen analysis using the modern analogue technique (Viau and Gajewski, 2009; Viau et al., 2012). Paleoclimatic data are available but with contradictory information. For instance, according to Viau and Gajewski (2009) and Viau et al. (2012), the MCA was cooler than the present day (1961-1990 AD) while warmer conditions were reconstructed in other parts of the country (Naulier et al., 2015). Thus, doubts persist regarding the recording of this climate anomaly in north-eastern Canada, as well as for the other 


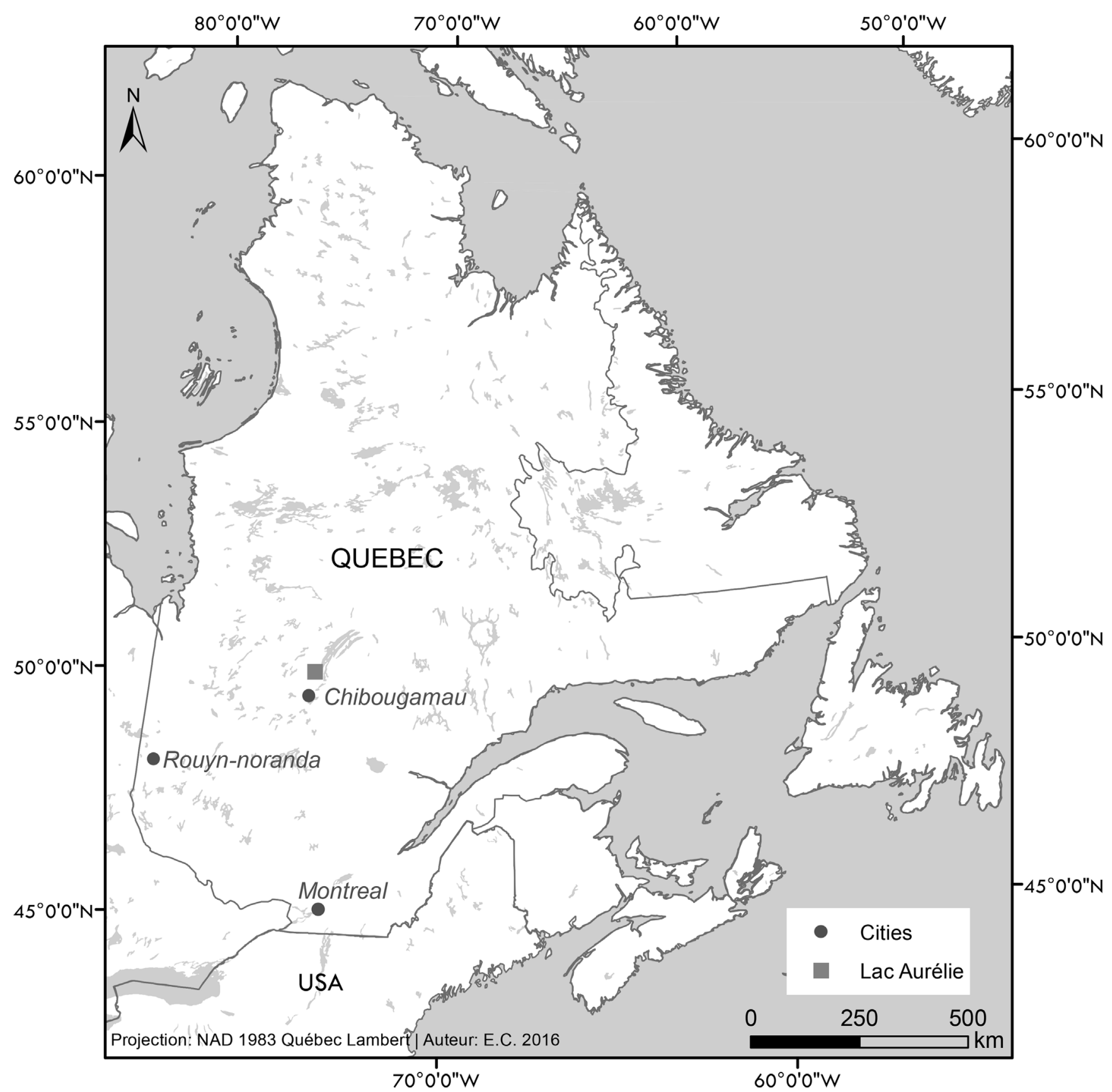

Figure 1. Location map of the study lake 'Lac Aurélie' in central Quebec, Canada.

major climate changes, notably those of weak amplitude, such as the Little Ice Age (LIA). Consequently, it is important to increase our knowledge of millennialscale temperature fluctuations using proxies able to capture low-amplitude climatic fluctuations. In this context, the main goal of this study is to present a new Holocene mean August air temperature reconstruction in the coniferous boreal forest of north-western Quebec (Canada) based on subfossil chironomid assemblages, allowing a discussion of the duration and amplitude of the HTM, MCA and LIA for this region.

\section{Methods}

\section{Study area and site}

The study site is located in central Quebec (Fig. 1), $66 \mathrm{~km}$ north of the town of Chibougamau. 'Lac Aurélie' (unofficial name; $50^{\circ} 25^{\prime} 12^{\prime \prime} \mathrm{N}, 74^{\circ} 13^{\prime} 47^{\prime \prime} \mathrm{W} ; 440 \mathrm{~m}$ a.s.l.) covers an area of $1 \mathrm{ha}$ and its maximum water depth $(10 \mathrm{~m})$ is in the central part of the lake. The lake is located in the black spruce feather moss bioclimatic domain (Saucier et al., 2009) dominated by black spruce (Picea mariana Mill.) and jack pine (Pinus banksiana Lamb.). Mean annual temperature from the closest meteorological station [Chapais 2: 1971-2000, $\left.49^{\circ} 47^{\prime} \mathrm{N}, 74^{\circ} 51^{\prime} \mathrm{W}\right]$ is $0.0 \pm 1.3^{\circ} \mathrm{C}$ with an August temperature average of $14.9 \pm 1.4^{\circ} \mathrm{C}$. Annual and August precipitation averages are 961 and $105 \mathrm{~mm}$, respectively (Environnement Canada, 2017). Further details about the study site characteristics can be found in El-Guellab et al. (2015).

\section{Coring, LOI analysis and chronology}

Two overlapping sediment cores (providing a continuous record) were taken in March 2010 on a frozen surface at the center of the lake using a modified Livingstone-type square-rod piston corer $(100 \times 5 \mathrm{~cm})$ (Wright et al., 1984). Sediments were covered in polyurethane and aluminum foil for transportation to the laboratory and preserved at 
Table 1. Radiocarbon dates at different depths. Dates were obtained from terrestrial plant macroremains. Chronology (not show in this study) was obtained from accelerated mass spectrometry (AMS) and has already been published by El-Guellab et al. (2015).

\begin{tabular}{|c|c|c|c|c|}
\hline Lab code & Depth (cm) & ${ }^{14} \mathrm{C}$ age $(\mathrm{a} B P)$ & Calibrated ${ }^{14} \mathrm{C}$ age range (cal a $\left.\mathrm{BP} ; 2 \sigma\right)$ & Materials \\
\hline Poz-35983 & $43-44$ & $2870 \pm 30$ & 3007 (2879-3136) & Plant macroremains \\
\hline Poz-35984 & $111-112$ & $3990 \pm 35$ & 4443 (4319-4568) & Plant macroremains \\
\hline Poz-36014 & $163-164$ & $4750 \pm 35$ & $5457(5329-5586)$ & Plant macroremains \\
\hline Poz-36016 & $220-221$ & $6140 \pm 40$ & 7047 (6931-7163) & Plant macroremains \\
\hline Poz-36017 & $236-237$ & $6490 \pm 40$ & 7396 (7317-7476) & Plant macroremains \\
\hline Poz-36018 & $326-327$ & $7460 \pm 50$ & 8279 (8185-8373) & Plant macroremains \\
\hline
\end{tabular}

Poz, Poznań Radiocarbon Laboratory.

$4{ }^{\circ} \mathrm{C}$ before they were sliced for analyses. The water-sediment interface was collected using a Kajak-Brinkhurst (KB) gravity corer (Glew, 1991). Sub-samples $\left(1 \mathrm{~cm}^{3}\right)$ were used for measuring the organic matter content by loss-on-ignition (LOI) at $550{ }^{\circ} \mathrm{C}$ for $4 \mathrm{~h}$ (Heiri et al., 2001). Radiocarbon dates [calibrated at 2 sigma ranges based on the Intcal13.14C data set (Reimer et al., 2013)] and chronology have already been published by El-Guellab et al. (2015). A summary is presented in Table 1.

\section{Chironomid analysis}

A total of 180 samples were analysed (Supporting Information, Table S1) at a temporal resolution varying between ca. 5 and 165 years (ca. 45 years on average). Chironomid head capsules were extracted from $2-\mathrm{cm}^{3}$ subsamples by soaking the samples overnight in $10 \% \mathrm{KOH}$. The subsamples were then water-rinsed through a sieve of $100 \mu \mathrm{m}$. The remnant was poured into a Bogorov tray and observed under a Leica stereomicroscope at a magnification of $20 \times$. Individual subfossil head capsules were picked with fine forceps and mounted on a microscope slide in a drop of Hydromatrix. Previous studies suggested that at least 50 head capsules should be mounted for temperature reconstructions (Larocque et al., 2001; Heiri and Lotter, 2010), but samples larger than 30 head capsules can also provide inferences below the error of the model (root mean square error of prediction, RMSEP) (Larocque et al., 2009; Larocque-Tobler et al., 2016). Taxonomic identification was made using a Motic microscope at a magnification of 400-1000 $\times$ following the taxonomic keys of Brooks et al. (2007), Larocque and Rolland (2006), Oliver and Roussel (1983) and Wiederholm (1983).

\section{Statistical analysis, paleoecological diagrams and constrained zonation}

A chironomid percentage diagram was drawn using C2 software (Juggins, 2003). Detrended correspondence analysis (DCA) was performed using ade4 and vegan packages from $R$ v3.2.2 (Borcard et al., 2011) on the $n$ (number of samples) by $p$ (number of taxa) chironomid matrix of percentages. Data were square root transformed to stabilize the variance. Rare taxa (present in only one sample or with a relative abundance always $<2 \%$ ) were removed from the analysis. The length of the first DCA axis determines whether the distribution of the data set along this axis is linear or unimodal (Borcard et al., 2011). Here, a gradient of 1.95 standard deviation units (SD) was obtained, suggesting linear techniques such as principal components analysis (PCA) were appropriate on our data set.

A PCA was then performed using $\mathrm{C} 2$ on the same data matrix used for the DCA. This method was coupled with a constrained sum-of-squares cluster analysis (CONISS) using the program ZONE version 1.2 (Juggins, 1991) to highlight major changes in assemblage composition (Grimm, 1987). The optimal number of significant zones created was determined by a broken stick model (Bennett, 1996). Percentage diagrams of warmer-than-today and colder-than-today taxa were made using the temperature optimum (Table 2) for each taxon obtained using the Eastern Canadian calibration set (see below). Percentages of eutrophic, oligo-mesotrophic, littoral and profundal taxa were calculated using ecological descriptions from Brooks et al. (2007). To better understand changes in the lake's conditions, ratios using these percentages were calculated. A $>1$ eutrophic/oligo-mesotrophic ratio suggests a tendency towards eutrophic conditions, whereas a ratio $<1$ suggests a tendency towards oligo-mesotrophic conditions. A littoral/profundal ratio $>1$ indicates a dominance of littoral taxa and a dominance of profundal taxa if it is $<1$.

\section{Transfer functions}

Two chironomid-based transfer functions were used to reconstruct mean August air temperature and evaluate their reliability in inferring past climate changes. The Eastern Canadian transfer function was first published by Larocque (2008) and was modified. Two lakes were added, and 11 lakes had their temperature measurements changed to mean August air temperature (Lakes $\mathrm{A}-\mathrm{H}$ ) as the earlier version of the calibration possessed only punctual measurements. In the new Eastern Canadian model, mean August temperature varied from 3 to $21{ }^{\circ} \mathrm{C}$ (instead of $27^{\circ} \mathrm{C}$ ) for a temperature gradient of $18{ }^{\circ} \mathrm{C}$. The new data will be available on the NOAA website once the paper is published. The calibration set comprises 75 lakes and 79 taxa. The WAPLS 999-bootstrap transfer function with two components yielded a correlation coefficient $\left(r^{2}\right.$ boot $)$ of 0.85 , an RMSEP of $1.67^{\circ} \mathrm{C}$ and a maximum bias of $3.05^{\circ} \mathrm{C}$.

The second transfer function combined data sets from Canada (Fortin et al., 2015). It comprises 485 lakes and 78 taxa. Mean August temperatures varied from -0.3 to $15.7^{\circ}$ $\mathrm{C}$ (gradient $=16^{\circ} \mathrm{C}$ ). It contains 52 of the 75 lakes in the Eastern Canadian transfer function of Larocque (2008). The correlation coefficient $\left(r_{\text {boot }}^{2}\right)$ is 0.73 , the RMSEP is $1.8^{\circ} \mathrm{C}$ and the maximum bias is $2.9^{\circ} \mathrm{C}$ (Fortin et al., 2015).

To verify if the transfer functions could be applied to the fossil assemblages of Lac Aurélie, we estimated if fossil assemblages had modern analogues using the minimum distance to modern assemblages (Overpeck et al., 1985). If the minimum distance was within the $1 \mathrm{st}-5$ th percentiles, the assemblages were considered as having 'good analogues'. If the distance was above the 20th percentile, the samples were considered as having no analogues. Furthermore, the goodness-of-Fit was calculated by passively adding downcore samples of Lac Aurélie into a Canonical Correspondence Analysis (CCA) analysis of the Eastern Canadian transfer function samples constrained by temperature (Heiri and 
Table 2. Occurrence of taxa in the sediment of Lac Aurélie (total of 179 samples). Comparison of temperature optima obtained with weighted averaging for the three transfer functions: (a) Eastern Canadian transfer function (Larocque, 2008); (b) Canadian transfer function (Fortin et al., 2015) and temperature categories.

\begin{tabular}{|c|c|c|c|c|c|}
\hline \multirow[t]{2}{*}{ Taxa identified in sediment } & \multirow{2}{*}{$\begin{array}{l}\text { Occurrence in } \\
\text { sediment }\end{array}$} & \multicolumn{2}{|r|}{ Optima } & \multicolumn{2}{|c|}{ Category } \\
\hline & & $\begin{array}{l}\text { (a) Eastern } \\
\text { Canada }\end{array}$ & (b) Canada & $\begin{array}{l}\text { Colder than today } \\
\qquad\left(15^{\circ} \mathrm{C}\right)\end{array}$ & $\begin{array}{l}\text { Warmer than today } \\
\qquad\left(15^{\circ} \mathrm{C}\right)\end{array}$ \\
\hline Ablabesmyia spp. & 131 & 14.2 & 4.5 & $X$ & \\
\hline Allopsectrocladius spp. & 33 & 15.8 & & & $x$ \\
\hline Brillia spp. & 2 & 14.4 & 10.4 & $x$ & \\
\hline Chaetocladius spp. & 34 & 13.8 & 9.2 & $x$ & \\
\hline \multicolumn{6}{|l|}{ Chironomus spp. } \\
\hline Chironomus anthracinus-type & 164 & & 9.7 & & \\
\hline Chironomus plumosus-type & 147 & 12.1 & $\begin{array}{c}\text { Merged into } \\
\text { Chironomus spp. }\end{array}$ & $X$ & \\
\hline Cladopelma lateralis-type & 75 & 14.7 & $\begin{array}{c}\text { Merged into } \\
\text { Chironomus spp }\end{array}$ & $x$ & \\
\hline Cladotanytarsus mancus-type & 87 & 13.5 & 10.2 & $x$ & \\
\hline Constempellina spp. & 34 & 12.2 & 9.3 & $x$ & \\
\hline Corynocera oliveri-type & 45 & 14.5 & 11.2 & $x$ & \\
\hline Corynoneura spp. & 43 & 10.4 & 8.3 & $x$ & \\
\hline Cricotopus/Orthocladius & & 7.3 & 7.9 & $x$ & \\
\hline Cricotopus spp. & 96 & & 7.7 & & \\
\hline Cryptochironomus spp. & 48 & 11.8 & $\begin{array}{l}\text { Merged with } \\
\text { Orthocladius }\end{array}$ & $X$ & \\
\hline Dicrotendipes nervosus-type & 119 & 14.9 & 11.3 & & \\
\hline Einfeldia spp. & 11 & 14.5 & 10.0 & $x$ & \\
\hline Endochironomus tendens-type & 54 & 12.9 & 11.8 & $X$ & \\
\hline Glyptotendipes pallens-type & 36 & 15.6 & 11.1 & & $x$ \\
\hline Heterotrissocladius spp. & & 14.7 & 10.9 & $X$ & \\
\hline H. grimshawi-type & 17 & & 7.7 & & \\
\hline H. marcidus-type & 17 & 12.4 & $\begin{array}{c}\text { Merged in } \\
\text { Heterotrissocladius }\end{array}$ & $X$ & \\
\hline H. subpilosus-type & 6 & 12.0 & $\begin{array}{c}\text { Merged in } \\
\text { Heterotrissocladius }\end{array}$ & $X$ & \\
\hline Labrundinia spp. & 2 & 8.2 & $\begin{array}{c}\text { Merged in } \\
\text { Heterotrissocladius }\end{array}$ & $X$ & \\
\hline Lauterborniella spp. & 60 & Not in model & 13.9 & & \\
\hline Limnophyes spp. & 19 & 22.6 & 13.4 & & $x$ \\
\hline Mesocricotopus spp. & 8 & 17.0 & 8.6 & & $x$ \\
\hline Micropsectra spp. & & 10.0 & 8.7 & $x$ & \\
\hline Micropsectra bidentata-type & 19 & & 6.2 & & \\
\hline Micropsectra insignilobus-type & 44 & 14.7 & Merged in Micropsectra & $x$ & \\
\hline Micropsectra radialis-type & 47 & 12.9 & Merged in Micropsectra & $x$ & \\
\hline Microtendipes pedellus-type & 130 & 9.4 & Merged in Micropsectra & $X$ & \\
\hline Nanocladius spp. & 3 & 13.5 & 11.0 & $x$ & \\
\hline Orthocladius spp. & 39 & 12.4 & 10.8 & $x$ & \\
\hline Pagastiella spp. & 26 & 13.5 & & $X$ & \\
\hline Parachaetocladius spp. & 2 & 14.5 & 11.2 & $x$ & \\
\hline Parachironomus varus-type & 5 & Not in model & Not in model & & \\
\hline Paracladius spp. & 1 & 13.6 & 10.4 & $x$ & \\
\hline Paracladopelma spp. & 2 & 7.4 & 4.5 & $X$ & \\
\hline Paracricotopus spp. & 1 & 13.8 & & $X$ & \\
\hline Parakiefferiella spp. & 40 & 11.0 & 9.6 & $X$ & \\
\hline Paratanytarsus spp. & 96 & 10.7 & 8.4 & $x$ & \\
\hline Paratendipes nudisquama-type & 13 & 12.8 & Merged in Tanytarsina & $X$ & \\
\hline Pentaneurini spp. & 83 & Not in model & 11.9 & & $x$ \\
\hline Phaenopsectra spp. & 9 & 14.9 & 9.3 & & \\
\hline Polypedilum nubeculosum-type & 101 & 14.9 & 11.0 & & \\
\hline Procladius spp. & 168 & 18.5 & 11.0 & & $x$ \\
\hline Psectrocladius septentrionalis-type & 55 & 14.5 & 9.5 & $x$ & \\
\hline Psectrocladius sordidellus-type & 141 & 12.2 & 10.6 & $X$ & \\
\hline Pseudochironomus spp. & 63 & 12.4 & 10.9 & $x$ & \\
\hline Pseudosmittia spp. & 7 & Not in model & 11.9 & & \\
\hline Rheocricotopus spp. & 1 & 15.5 & 8.5 & & $x$ \\
\hline Sergentia coracina-type & 20 & Not in model & 9.1 & & \\
\hline Smittia spp. & 5 & 25.8 & 7.1 & & $x$ \\
\hline Stempelinella spp. & 21 & 11.6 & Not in model & $x$ & \\
\hline \multirow[t]{2}{*}{ Stenochironomus spp. } & 2 & 14.6 & 10.6 & $x$ & \\
\hline & 1 & $\begin{array}{c}\text { Not in model } \\
7.9\end{array}$ & $\begin{array}{c}\text { Not in model } \\
7.4\end{array}$ & $x$ & \\
\hline
\end{tabular}


Table 2. (Continued)

\begin{tabular}{|c|c|c|c|c|c|}
\hline \multirow[t]{2}{*}{ Taxa identified in sediment } & \multirow{2}{*}{$\begin{array}{l}\text { Occurrence in } \\
\text { sediment }\end{array}$} & \multicolumn{2}{|r|}{ Optima } & \multicolumn{2}{|c|}{ Category } \\
\hline & & $\begin{array}{l}\text { (a) Eastern } \\
\text { Canada }\end{array}$ & (b) Canada & $\begin{array}{l}\text { Colder than today } \\
\left(15^{\circ} \mathrm{C}\right)\end{array}$ & $\begin{array}{l}\text { Warmer than today } \\
\qquad\left(15^{\circ} \mathrm{C}\right)\end{array}$ \\
\hline Tanytarsus lugens-type & 145 & & 8.3 & & \\
\hline Tanytarsus mendax-type & 145 & 13.5 & Merged in Tanytarsina & & $\mathrm{x}$ \\
\hline Tanytarsus pallidicornis-type & 74 & 14.1 & Merged in Tanytarsina & & $x$ \\
\hline Tanytarsus spp. & 173 & 12.9 & Merged in Tanytarsina & $\mathrm{x}$ & \\
\hline Tanytarsus glabrescens-type & 95 & 12.6 & Merged in Tanytarsina & $\mathrm{x}$ & \\
\hline Tanytarsus with spur on antenna & 44 & 15.8 & Merged in Tanytarsina & & $\mathrm{x}$ \\
\hline Thiennemaniella spp. & 16 & 15.3 & Merged in Tanytarsina & & $\mathrm{x}$ \\
\hline Thiennemanyia spp. & 3 & Not in model & 9.9 & & \\
\hline Xenochironomus spp. & 1 & 11.7 & Not in model & $\mathrm{x}$ & \\
\hline Zalutschia mucronata-type & 49 & Not in model & Not in model & & \\
\hline $\begin{array}{l}\text { Number of taxa not included in the } \\
\text { training set }\end{array}$ & & 8 & 19 & & \\
\hline Maximum temperature $\left({ }^{\circ} \mathrm{C}\right)$ & & 25.8 & 13.9 & & \\
\hline Minimum temperature $\left({ }^{\circ} \mathrm{C}\right)$ & & 7.3 & 4.5 & & \\
\hline
\end{tabular}

Lotter, 2010), using the CANOCO 4.5 program. If the distance between downcore and transfer function samples was above the 10th percentile, the downcore sample was characterized as not having a good fit to temperature (Andrén et al., 2015). Thirdly, a percentage of the fossil taxa present in the training set was calculated. A reconstruction should be considered adequate if samples have high percentages of fossil taxa present in the transfer function. Finally, to interpret and compare the chironomid-inferred temperature with other paleoecological climate records, a LOESS regression (span $=0.2$ ) was applied.

\section{Results}

\section{Organic matter content}

The 335-cm-long core was composed entirely composed of gyttja. At the bottom of the core $(326-327 \mathrm{~cm})$, an age of ca. 8.2-8.4k cal a BP (2 sigma range) was determined (Table 1 ).

The uppermost $22 \mathrm{~cm}$ of the sediment was used completely for biological analysis, and thus LOI analysis could not be performed for this section of the core. Before ca. $7.7 \mathrm{k} \mathrm{cal} \mathrm{a}$ $\mathrm{BP}$, the proportions of organic matter were below $60 \%$. Between ca. 7.7 and $7.8 \mathrm{k}$ cal a BP, the percentages were very low $(<20 \%)$ and the sediment was composed of a sandy layer.

\section{Chironomid analysis}

Of the 180 samples analyzed, one $(48 \mathrm{~cm})$ did not have any head capsules. Fifteen samples with fewer than 30 head capsules were merged for a total of 164 samples. Of those 164,35 samples had head capsule numbers between 32 and 49.5 , and thus $80 \%$ of the samples had more than 50 head capsules. In total, 63 taxa were identified to genus or species morphotypes. PCA axes one and two had eigenvalues of 0.25 and 0.11 , respectively. The 25 most abundant taxa (percentages reaching at least $10 \%$ ) are shown in Fig. 2(A).

Five significant zones (Ach-1 to Ach-5) were numerically identified (Fig. 2A). In zone Ach-1 (ca. 8.3-6.7k cal a BP), the PCA axis one scores were positive. This zone was dominated by taxa with temperature optima above $13.5{ }^{\circ} \mathrm{C}$ (Fig. 2B) such as Dicrotendipes nervosus-type, Procladius spp., Tanytarsus mendax-type, Polypedilum nubeculosum-type and Endochironomus tendens-type. Colder-than-today taxa (Fig. 2B) reached $90 \%$ at the beginning of the record (8.2-8.0k cal a BP) and many of the cold indicators such as Corynocera oliveri-type, Micropsectra radialis-type and Heterotrissocladius marcidus-type (Fig. 2a) had their highest percentages of the record in the first few samples of this zone. The lake was possibly oligotrophic during this zone, as the ratio of eutrophic/ oligo-mesotrophic taxa was below 1 (Fig. 2bB). Littoral taxa dominated after $8.1 \mathrm{k}$ cal a BP.

In zone Ach-2 (ca. 6.7-5.5k cal a BP), PCA axis 1 scores were below 0 (Fig. 2B). Warm indicators had percentages generally below average except in one sample at ca. $6.2 \mathrm{k}$ cal a BP. Tanytarsus spp. dominated the assemblages with percentages around $40 \%$. Chironomus plumosus-type, C. anthracinus-type, T. lugens-type and Procladius spp. were also well represented in the assemblages. Unstable conditions were identified, with oscillating eutrophic/oligo-mesotrophic and littoral/profundal ratios being recorded (Fig. 2B).

Zone Ach-3 (ca. 5.5-4.9k cal a BP) was characterized by PCA axis 1 scores above 0 . The percentages of warm taxa were above average, and the assemblages were dominated by D. nervosus-type, T. mendax-type, Procladius spp., P. nubeculosum-type, C. mancus-type and Pseudochironomus spp. The ratios of eutro/oligo-mesotrophic taxa were slightly below 1, suggesting mesotrophic conditions. Littoral taxa dominated.

In zone Ach-4 (ca. 4.9-0.6k cal a BP), PCA scores were all below 0 . This zone was divided into two subzones based on changes in taxa percentages and PCA axis 2 scores, which were above 0 after ca. $1.5 \mathrm{k}$ cal a BP.

In subzone Ach-4a (ca. 4.9-1.7k cal a BP), the percentages of warm taxa decreased below average, suggesting conditions colder than today. The dominant taxon was Tanytarsus spp., a taxon which is considered an indicator of colder-than-today conditions. The lake had a tendency towards oligo-mesotrophy with ratios generally below 1 . Littoral taxa dominated.

In subzone Ach-4b $(1.7 \mathrm{k}$ cal a BP to $600 \mathrm{cal}$ a BP), changes in PCA axis 2 scores were observed and the number of head capsules was generally between 30 and 70. Both cold and warm taxa were at average values, suggesting a slight climatic amelioration to warmer conditions. The main changes in taxa were the strong decrease in Tanytarsus spp. 

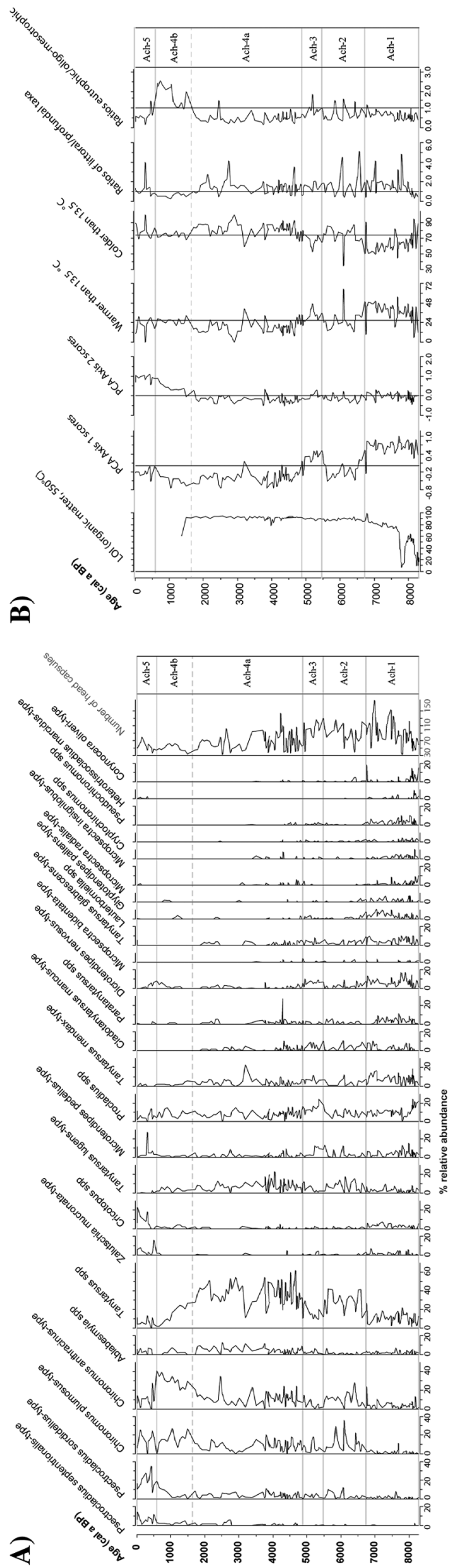

percentages and the increase in both Chironomus types. These increases in Chironomus types were linked to sharp increases in eutrophic/oligo-mesotrophic ratios and decreases in littoral/profundal taxa (Fig. 2B); Chironomus types are considered as eutrophic and profundal taxa (Brooks et al., 2007).

During zone Ach-5 (ca. $600 \mathrm{cal}$ a BP to present), PCA axis 1 scores remained below 0 and PCA axis 2 scores continued to increase. Cold taxa were above average while warm taxa were below average, suggesting colder conditions. P. sordidellus-type, $P$. septentrionalis-type, Zalutschia mucronatatype and Psectrocladius spp. and Cricotopus spp. dominated for the first time. Trophic conditions had a tendency towards oligo-mesotrophy with ratios below 1 and littoral taxa were dominant.

\section{Chironomid-inferred temperature reconstructions}

The temperature reconstruction patterns obtained by the two transfer functions are similar (Fig. 3). However, the Canadian transfer function provided estimates which were $2-3{ }^{\circ} \mathrm{C}$ lower than those of the Eastern Canadian model. The temperature anomalies obtained from the Canadian model were mostly inferred as lower than today, which does not fit with known climate patterns. The Eastern Canadian reconstruction was thus used to look at details of climate change.

The PCA axis 1 scores and inferred temperatures with the Eastern Canadian model had a significant correlation ( $r_{\text {Pearson }}$ $=0.62, p<0.05$ ). Low temperatures were recorded before $8 \mathrm{k}$ cal a BP with an average anomaly of $-0.8^{\circ} \mathrm{C}$ (Fig. 3). Temperatures increased to reach a maximum around $\mathrm{ca}$. $8 \mathrm{k}$ cal a BP and remained high until ca. $6.7 \mathrm{k} \mathrm{cal} \mathrm{a} \mathrm{BP} \mathrm{with} \mathrm{an}$ average anomaly of $0.9^{\circ} \mathrm{C}$. During zone Ach-2 (ca. 6.7-5.5k cal a BP), temperatures were generally lower than previously with an average anomaly of $-0.5{ }^{\circ} \mathrm{C}$. During zone Ach-3 (ca. $5.5-4.9 \mathrm{k}$ cal a BP), the inferred temperatures were similar to today's with average anomaly of $-0.2^{\circ} \mathrm{C}$. In zone Ach-4, temperatures were lower than today $\left(-1.4{ }^{\circ} \mathrm{C}\right.$ in average). Changes occurred at around $1.2-1.1 \mathrm{k}$ cal a BP, with an average anomaly of $0.7^{\circ} \mathrm{C}$, while the zone had lower temperatures than today $\left(-0.8{ }^{\circ} \mathrm{C}\right)$, on average. During zone Ach-5 (ca. 600 cal a BP to present) the average anomaly was $-2.1^{\circ} \mathrm{C}$.

\section{Discussion}

\section{Ecological interpretation}

The first axis of the PCA could be interpreted as a climate gradient probably related to temperature; the correlation $\left(r_{\text {Pearson }}\right)$ between PCA axis 1 scores and the temperature reconstruction was 0.62 . Many taxa had higher temperature optima in the Eastern Canadian model than in the Canadian transfer function (Table 2). Most of the colder-than-today indicators are similarly characterized in Brooks et al. (2007).

Changes in PCA axis 2 scores starting at ca. $1.5 \mathrm{k} \mathrm{cal} \mathrm{a} \mathrm{BP}$ with PCA axis 1 scores remaining below 0 suggest that temperature is not the only factor influencing the changes in chironomid assemblages through time. In our core, PCA axis 2 scores were correlated with the ratios of oligo-meso/ eutrophic taxa and with the ratio of littoral/profundal taxa. The effects of nutrients and water depth on chironomids have been previously shown (Lotter et al., 1997; Larocque et al., 2006) and models to reconstruct both parameters were developed (Langdon et al., 2006; Engels et al., 2012). As most members of the Tanytarsini tribe are both littoral (except $T$. lugens-type) and eutrophic, their decrease starting at ca. 


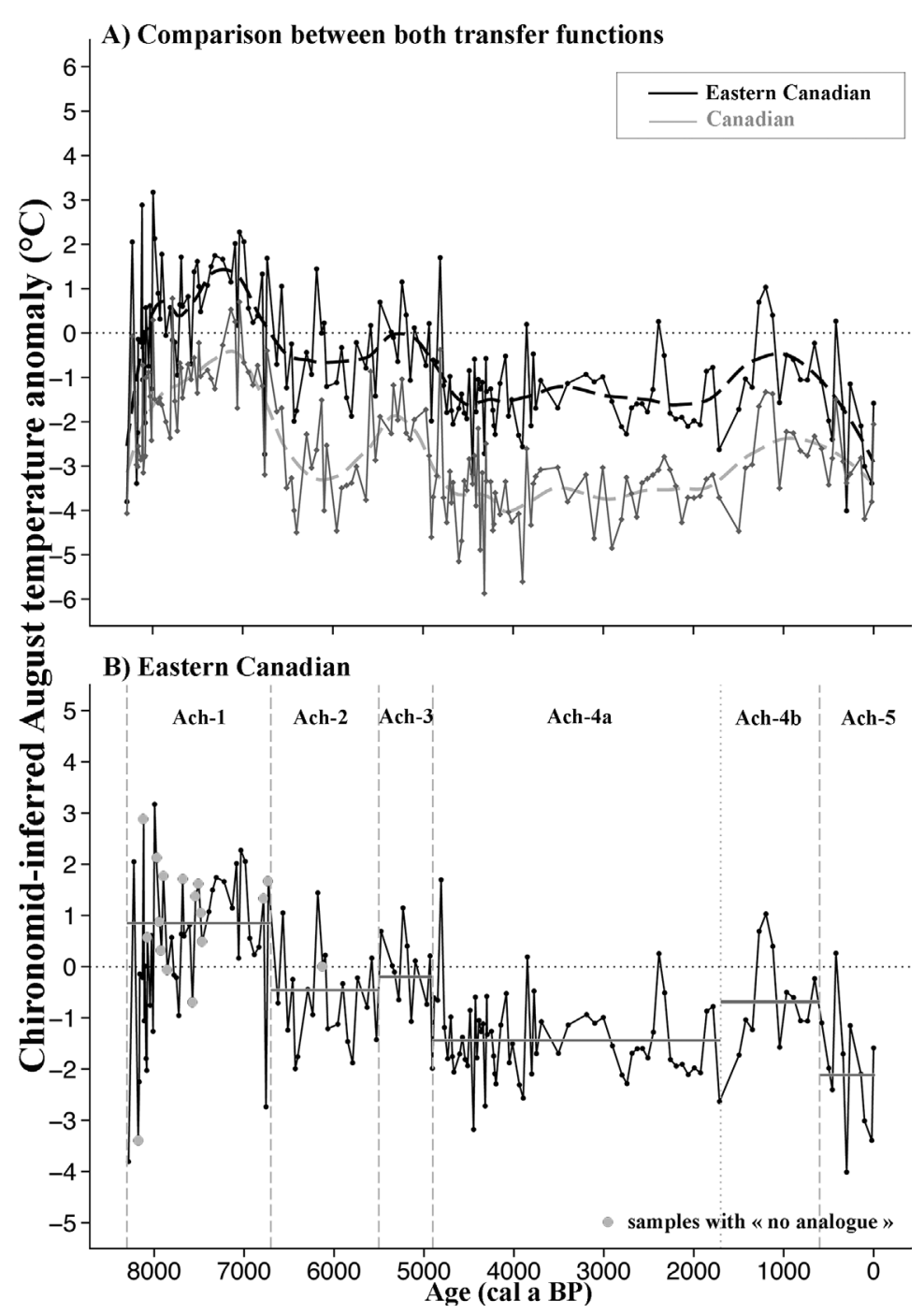

Figure 3. Chironomid-inferred August air temperature anomaly $\left({ }^{\circ} \mathrm{C}\right)$ at Lac Aurélie. (A) Comparison between the Eastern Canadian transfer function and the Canadian transfer function of Fortin et al. (2015). The dashed curves indicate the smoothed reconstructions (loess, span 0.2). (B) Details of the Eastern Canadian transfer function, which illustrate a more reliable record. The vertical lines indicate the zonation obtained from the chironomid stratigraphy (Fig. 2A). The horizontal bold lines indicate the average anomaly of the chironomid zones.

$1.5 \mathrm{k}$ cal a BP identifies trophic levels and water depth as two of the main drivers of the observed ratios. In zone $4 \mathrm{~b}(1.5 \mathrm{k}$ cal a BP), profundal taxa dominated (as suggested by ratios above 1), probably due to the increase in both types of Chironomus. These taxa have hemoglobin (Walshe, 1950), allowing them to survive short periods of oxygen depletion (Brooks et al., 2007), suggesting that oxygen availability might have changed during this period. Percentages of Polypedilum nubeculoseum-type, associated with macrophytes, also increased during this time. The presence of macrophytes has been shown to influence chironomids (Langdon et al., 2008) and lower oxygen levels have been recorded in lakes with a developed macrophyte community (Rose and Crumpton, 1996). In zone 5, represented by a further increase in PCA axis 2 scores, the percentages of both Psectrocladius types and Cricotopus spp. largely increased with Pentaneurini spp. and Ablabesmyia spp. Psectrocladius is often associated with macrophytes (Brodersen et al., 2001; Langdon et al., 2008) and is acidophilic (Pinder and Morley, 1995), as $\mathrm{pH}$ is another factor affecting chironomids (Orendt, 1999). Cricotopus, Ablabesmyia and Zalutschia spp. are associated with vegetation (Brooks et al., 2007), while Zalutschia spp. and Ablabesmyia occur in acidified lakes (Brooks et al., 2007).
Based on the changes in the chironomid communities, macrophytes, changes in oxygen and $\mathrm{pH}$ might have influenced the chironomid assemblages since ca. $1.5 \mathrm{k}$ cal a BP. However, low-variability climate changes, such as for the LIA, have also been reconstructed from our assemblages (see below), which suggests that, although other factors influenced the assemblages, the pattern of chironomid-inferred temperature changes was still adequately reconstructed. Luoto and Nevalainen (2017) have shown that chironomids can reconstruct climate effectively even under the influence of eutrophication and pollution.

\section{Reliability of the chironomid inferred temperature reconstructions}

The Canadian transfer function of Fortin et al. (2015) used a very large number of lakes (435) and would, at first, be considered as the most suitable to reconstruct climate in a lake in the boreal forest of Quebec. However, only a few of these lakes have August temperatures above $14^{\circ} \mathrm{C}$ and the residuals (fig. 4 in Fortin et al., 2015) suggest that higher temperatures will be underestimated. As Lac Aurélie's current August temperature is $15{ }^{\circ} \mathrm{C}$, which is at the end of the gradient of the Canadian transfer function, its present-day 
temperature should possibly be underestimated with the model of Fortin et al. (2015). If the temperatures were higher in the past, the inferences would also be lower than expected. Furthermore, because the temperature gradient is relatively small ( -0.3 to $15.7^{\circ} \mathrm{C}$ ) and contains mostly lakes of low temperatures, the optimum for each taxon is relatively low (4.5-13.9 ${ }^{\circ} \mathrm{C}$; Table 2), which explains why the reconstruction is $2-3{ }^{\circ} \mathrm{C}$ lower than the one obtained with the other training set. In addition, Fortin et al. (2015) merged certain taxa to a lower taxonomic level, as identified in some of the calibration sets. Consequently, this grouping could induce less realistic inferred temperature reconstructions. However, it should be remembered that the pattern of changes is very similar between each transfer function.

The Eastern Canadian transfer function (Larocque, 2008) is an extended version of the 52 lakes from Larocque et al. (2006) that was used in the Canadian model of Fortin et al. (2015). It contains a few lakes north $\left(3{ }^{\circ} \mathrm{C}\right)$ and south $\left(21^{\circ} \mathrm{C}\right)$, thus increasing the temperature gradient $\left(3-21^{\circ} \mathrm{C}\right)$. Although it comprises fewer lakes (75) than the Canadian transfer function, the increased gradient might provide more accurate optima. The temperature optima in the Eastern Canadian model vary between 7.5 and $20.5{ }^{\circ} \mathrm{C}$ (Table 2). However, this training set does not include any lakes with August temperatures between 16.8 and $19{ }^{\circ} \mathrm{C}$, temperatures which might have been experienced at Lac Aurélie in the past, so many of the fossil samples did not resemble those found in the training set. To obtain the best coverage (larger gradient and lakes evenly distributed along the gradient) temperatures that may have been experienced, lakes with temperatures between 16 and $19{ }^{\circ} \mathrm{C}$ should be added. Unfortunately, such data were not available as lakes were not yet sampled within this range. We assume that the inferences were possibly lower than they should be. However, as weighted average partial least squares (WA-PLS) is based on temperature optima for each taxon found in the fossil record, it is important to include as many fossil taxa as possible in the training set. This is the case in the fossil record of Lac Aurélie, with all samples having more than $83 \%$ of their taxa found in the training set lakes, and 133 of 179 samples $(74 \%)$ having fossil taxa represented in the training set above $95 \%$.

A problem that needs to be considered in evaluating the accuracy of a model is the absence of modern analogues. Seventeen of the 164 samples had no modern analogues (Fig. 3). These samples were mainly in the lower portion of the sedimentary core $(<6.7$ cal a BP). Nevertheless, WA-PLS methods perform well in non-analogue situations because the estimates are based on modeled taxon temperature optima assuming unimodal responses to temperature (Birks and Birks, 1998). This allows the model to infer temperatures outside the range of the calibration set. In these cases, comparison with other regional paleoclimate records is essential to evaluate the reliability of the temperature reconstruction. The applicability of the Eastern Canadian transfer function to the Lac Aurélie samples was further assessed using goodness-offit to temperature. None of the Lac Aurélie samples was above the 10th percentile, so we assume that all downcore samples had good fit to temperature.

\section{2k cal a BP cold event and Holocene Thermal Maximum}

After the retreat of the last remnant of the glacier (Dyke, 2004), the chironomid-inferred temperature in Lac Aurélie is $2-3{ }^{\circ} \mathrm{C}$ lower than today in three samples around ca. $8.2 \mathrm{k}$ cal a BP (8282-8175 cal a BP). This might represent the so-called 8.2k cal a BP event (Alley et al., 1997). The Greenland ice core record indicates that temperatures fell by ca. $3.3{ }^{\circ} \mathrm{C}$ and this period lasted $150 \mathrm{cal}$ years (Kobashi et al., 2007; Thomas et al., 2007). Our results correspond to the ice core record in both timing (ca. 110 years, limited by our sampling technique) and amplitude of change $\left(-3^{\circ} \mathrm{C}\right)$.

The HTM lasted between 11 and $5 \mathrm{k}$ cal a BP in the Northern Hemisphere, but with many regional variations (Renssen et al., 2009). Based on pollen data from sites in north-western Quebec, Viau and Gajewski (2009) highlighted high temperatures between 6 and $2 \mathrm{k}$ cal a BP. Our results show summer temperatures higher than or similar to today between ca. 8.3 and $4.9 \mathrm{k}$ cal a BP, but with a sharp decline around ca. $6.5 \mathrm{k}$ cal a BP. Our reconstruction matches paleoclimate records obtained from the Arctic (GISP2 ice core; Kobashi et al., 2010), from pollen across north-eastern America (Viau et al., 2006) and from a chironomid record on Baffin Island (Axford et al., 2009) (Fig. 4A). The increase in temperature $\left(+2-3{ }^{\circ} \mathrm{C}\right.$ in three samples at the beginning of the record) was similarly recorded in the ice core $\left(+3^{\circ} \mathrm{C}\right)$ and from Baffin Island $\left(+4{ }^{\circ} \mathrm{C}\right)$ (Fig. 4a). However, the combined pollen records registered an increase in temperature of about only $1{ }^{\circ} \mathrm{C}$ (Viau et al., 2006). This could be due to the merging of various fossil records across north-eastern Canada. Stacking of records of different amplitudes at many locations, as per Viau et al. (2006), decreases the average variation. Another reason for differences in amplitude is the use of different models to infer climate. The modern analogue technique generally provides changes of much lower amplitude than the weighted average method used here (Birks, 2003). The amplitude of change has been shown to reach $5{ }^{\circ} \mathrm{C}$ at the highest latitudes, between 2.5 and $5{ }^{\circ} \mathrm{C}$ in our study region, and smaller amplitudes at lower latitudes (Renssen et al., 2012). Thus, the amplitude of change reconstructed by chironomids at Lac Aurélie seems to be plausible. Furthermore, the decrease in temperature from the late Holocene (4.5-1.5k cal a BP) could be the result of the cold and wet Neoglacial period (Viau and Gajewski, 2009).

\section{Medieval Climate Anomaly}

Chironomid assemblages showed an increase in temperature $\left(+0.7^{\circ} \mathrm{C}\right)$ around $1.1-1.2 \mathrm{k}$ cal a BP (Figs 3 and 4 ) probably corresponding to the MCA recorded by various proxies in the Northern Hemisphere (Mann et al., 2009). The pollen data results of Viau et al. (2006) recorded across North America agree with ours. Viau and Gajewski (2009) also recorded this warming period in northern Quebec. Rolland et al. (2009) inferred a warming period between 1160 and 1360 AD on Southampton Island (Nunavut, Canada) based on chironomid assemblages. In the central Northwest Territories (Canada), chironomid-inferred temperature reconstructions have shown a warming which occurred between 1 and $0.7 \mathrm{k}$ cal a BP (Upiter et al., 2014). Arseneault and Payette (1997) also observed a warming trend based on tree rings at the treeline in north-western Quebec. When comparing our record to other proxy records (Fig. 4B), the period around ca. 1.5-1k cal a BP is clearly identified as warmer than today with a concomitant timing (PAGES 2k Consortium, 2013). Using chironomids, Millet et al. (2009) reconstructed a warming of $1.3^{\circ} \mathrm{C}$ in the French Alps. Larocque-Tobler et al. (2012) showed increased temperatures $\left(1-2^{\circ} \mathrm{C}\right)$ during the MCA in two Swiss lakes and the composite records composed of treerings and diatoms inferred an increase of $0.5^{\circ} \mathrm{C}$ (Trachsel et al., 2012), exemplifying that combining different fossil proxies/sites smooths the record. 


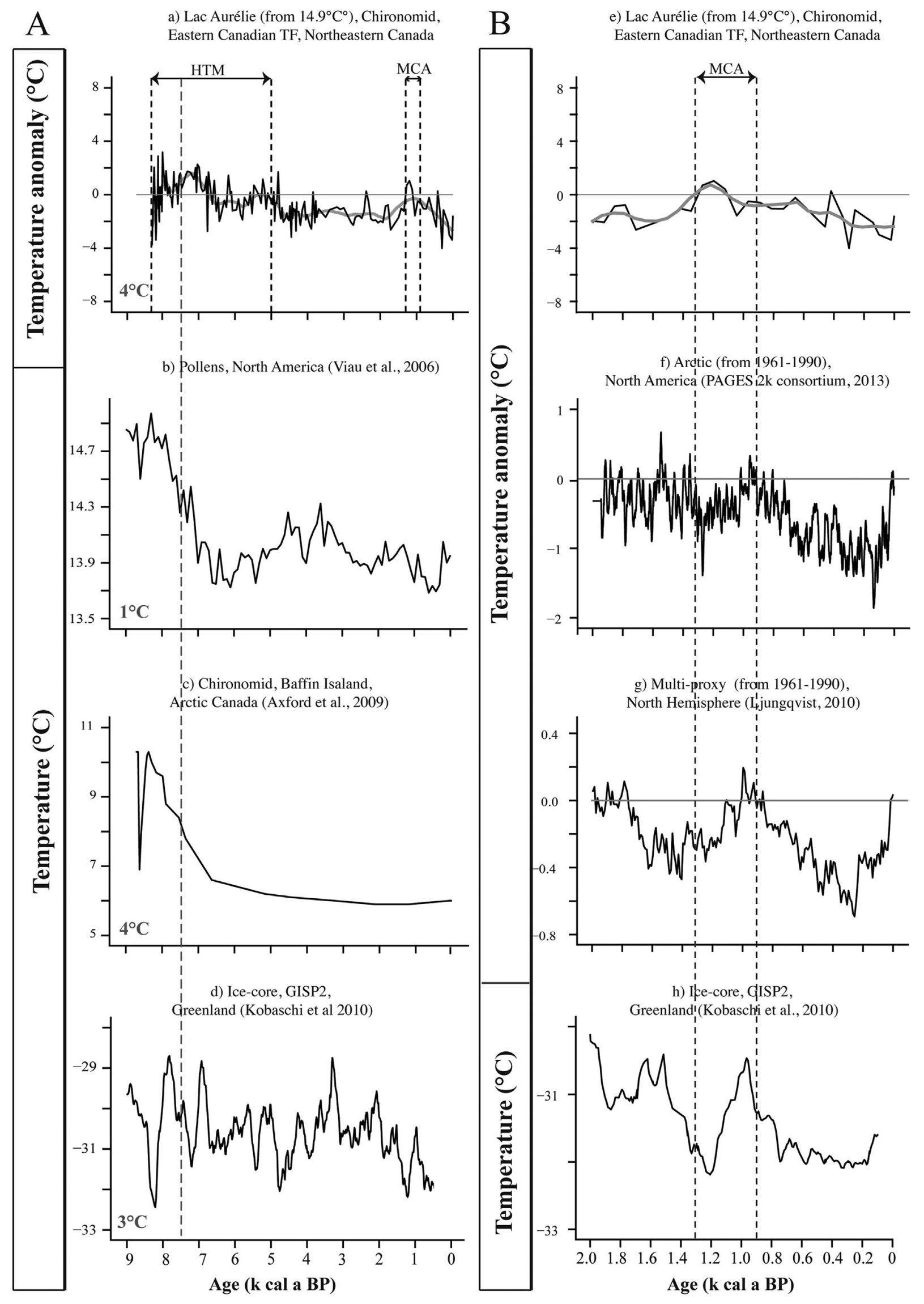

Figure 4. (Continued). 
Figure 4. (A) Comparison of various temperature reconstructions during the past $9 \mathrm{k}$ cal a BP. The data were obtained from the National Oceanic \& Atmospheric Administration (NOAA) World Data Center for Paleoclimatology. (a) Chironomid-inferred August mean temperature anomaly, span of 0.2 (black line) and 95\% confidence interval (light grey shading) at Lac Aurélie for the past $8.5 \mathrm{k}$ cal a BP related to today's study area temperature $\left(15.0^{\circ} \mathrm{C}\right.$ ) (this study). (b) Pollen-inferred North American mean July temperatures for the past $9 \mathrm{k}$ cal a BP (Viau et al., 2006). (c) Chironomid-inferred July temperatures at Lake CF8 (Baffin Island, Canada) for the past 9k cal a BP (Axford et al., 2009). (d) GISP2 ice-core inferred Greenland temperatures for the past 9k cal a BP (Kobashi et al., 2010). (B) Comparison of different temperature reconstructions during the past $2 \mathrm{k}$ cal a BP. (e) Chironomid-inferred August mean temperature anomaly, span of 0.2 (black line) and $95 \%$ confidence interval (light grey shading) at Lac Aurélie related to today's temperature of at Chibougamau $\left(15.0^{\circ} \mathrm{C}\right)$ (this study). (f) Northern Hemisphere Arctic temperatures from 1961 to 1990 (PAGES 2k Consortium, 2013). (g) Multi-proxy inferred extra-tropical Northern Hemisphere $\left(90^{\circ}-30^{\circ} \mathrm{N}\right)$ decadal mean temperature anomaly (dark line) related to 1996-1990 with 2 standard deviation error bars (light grey shading) (Ljungqvist, 2010). (h) GISP2, ice-core inferred Greenland temperature (Kobashi et al., 2010).

During this period, PCA axis 2 scores suggested that factors other than climate (macrophytes, oxygen, $\mathrm{pH}$ ) affected the chironomid assemblages at Lac Aurélie. However, because the MCA seems to have been plausibly reconstructed, it appears that it did not completely affect the relationship with temperature.

\section{Little Ice Age}

The LIA is a colder-than-today period which occurred between 1300 and 1850 AD (Matthews and Briffa, 2005) and is defined in north-eastern Canada between the late 1500s to the late 1800s (Payette and Delwaide, 2004). During the LIA, the cooling with the largest amplitude occurred in northern Quebec (Viau and Gajewski, 2009). The temporal resolution of our record decreases during this period (about 40-80 years). The main features of this period are recognized with the start of the cooling being recorded at around 1390 AD and punctuated by a short warming period. Three colder periods are generally seen in high-resolution records at around 1650, 1779 and 1850 AD (Mann and Jones, 2003; Mann et al., 2008). At Lac Aurélie, the two lowest temperatures inferred were temporally close to these high-resolution records at ca. 1663 and $1900 \mathrm{AD}$. However, the colder-thantoday temperatures of $1{ }^{\circ} \mathrm{C}$ (average $0.5^{\circ} \mathrm{C}$ ) were inferred in only three samples and should be considered with caution. This amplitude is consistent with high-resolution chironomid records from Switzerland (i.e. Larocque-Tobler et al., 2012), but larger than dendrochronological records in northern Europe (Moberg et al., 2005) and combined proxy records from Switzerland (Trachsel et al., 2010).

In conclusion, despite methodological limits to the transfer function, good correspondences between our climate reconstruction and those obtained at other sites and from diverse proxies suggests that chironomids are useful to detect temperature changes at this site. Main climate events such as the HTM, the Neoglacial period, the MCA and the LIA have been recorded by chironomids at Lac Aurélie. Hence, further high-resolution regional studies, based on chironomid analyses, should be conducted to improve our understanding of past natural climate changes in boreal forest ecosystems.

\section{Supplementary Information}

Table S1. Chironomid counts (percentage) for each level Lac Aurélie core.

Acknowledgements. This research was funded by the Natural Sciences and Engineering Research Council of Canada (NSERC), the Centre National de la Recherche (France), and the Institut Écologie \& Environnement through the GDRI 'Forêts Froides'. We thank the French University Institute for its support. Our thanks to R. Julien and L. Bremond for their participation in fieldwork. We greatly appreciate the contribution of Dr Andrew Scott Medeiros for providing the complete data of the Fortin et al. (2015) training set. We thank B. Fréchette for her advice and E. Chaste for technical support.
Abbreviations. DCA, detrended correspondence analysis; HTM, Holocene Thermal Maximum; LIA, Little Ice Age; LOI, loss-onignition; MCA, Medieval Climate Anomaly; PCA, principal component analysis; RMSEP, root mean square error of prediction; WA-PLS, weighted average partial least squares.

\section{References}

Alley RB, Mayewski PA, Sowers T et al. 1997. Holocene climatic instability: a prominent, widespread event 8200 year ago. Geology 25: 483-486.

Andrén E, Klimaschewski A, Self AE et al. 2015. Holocene climate and environmental change in north-eastern Kamchatka (Russian Far East), inferred from a multi-proxy study of lake sediments. Global and Planetary Change 134: 41-54.

Arseneault D, Payette S. 1997. Reconstruction of millennial forest dynamics from tree remains in a subarctic tree line peatland. Ecology 78: 1873-1883.

Axford Y, Briner JP, Miller GH et al. 2009. Paleoecological evidence for abrupt cold reversals during peak Holocene warmth on Baffin Island, Arctic Canada. Quaternary Research 71: 142-149.

Bennett KD. 1996. Determination of the number of zones in a biostratigraphical sequence. New Phytologist 132: 155-170.

Birks HH. 2003. The importance of plant macrofossils in the reconstruction of Lateglacial vegetation and climate: examples from Scotland, western Norway, and Minnesota, USA. Quaternary Science Reviews 22: 453-473.

Birks HJB, Birks HJB. 1998. DG Frey and ES Deevey Review 1: numerical tools in palaeolimnology-Progress, potentialities, and problems. Journal of Paleolimnology 20: 307-332.

Borcard D, Gillet F, Legendre P. 2011. Numerical Ecology with R. Springer: New York.

Brodersen KP, Odgaard BV, Vestergaard O et al. 2001. Chironomid stratigraphy in the shallow and eutrophic Lake Sobygaard, Denmark: chironomid-macrophyte co-occurrence. Freshwater Biology 46: 253-267.

Brooks SJ. 2006. Fossil midges (Diptera: Chironomidae) as palaeoclimatic indicators for the Eurasian region. Quaternary Science Reviews 25: 1894-1910.

Brooks SJ, Langdon PG, Heiri O. 2007. The identification and use of Palaearctic Chironomidae in palaeoecology. QRA Technical Guide No. 10. QRA: London.

Dyke AS. 2004. An outline of North American deglaciation with emphasis on central and northern Canada. Developments in Quaternary Sciences 2: 373-424.

El-Guellab A, Asselin H, Gauthier S et al. 2015. Holocene variations of wildfire occurrence as a guide for sustainable management of the northeastern Canadian-Boreal forest. Forest Ecosystems 2: 1.

Engels S, Cwynar LC, Rees ABH et al. 2012. Chironomid-based water depth reconstructions: an independent evaluation of site-specific and local inference models. Journal of Paleolimnology 48: 693-709.

Environnement Canada. 2017. Normales Climatiques au Canada, 1971-2000, service Météorologique du Canada. Available at: climate.weatheroffice.ec.gc.ca/climate_normals/.

Esper J, Frank D. 2009. The IPCC on a heterogeneous Medieval Warm Period. Climatic Change 94: 267-273.

Fortin M-C., Medeiros AS, Gajewski K et al. 2015. Chironomidenvironment relations in northern North America. Journal of Paleolimnology 54: 223-237. 
Glew JR. 1991. Miniature gravity corer for recovering short sediment cores. Journal of Paleolimnology 5: 285-287.

Grimm EC. 1987. CONISS: a FORTRAN 77 program for stratigraphically constrained cluster analysis by the method of incremental sum of squares. Computers and Geosciences 13: 13-35.

Heiri O, Ilyashuk B, Millet L et al. 2015. Stacking of discontinuous regional palaeoclimate records: chironomid-based summer temperatures from the Alpine region. The Holocene 25: 137-149.

Heiri O, Lotter AF. 2010. How does taxonomic resolution affect chironomid-based temperature reconstruction? Journal of Paleolimnology 44: 589-601.

Heiri O, Lotter AF, Lemcke G. 2001. Loss on ignition as a method for estimating organic and carbonate content in sediments: reproducibility and comparability of results. Journal of Paleolimnology 25: 101-110.

Juggins S. 1991. Zone Version 1.2. DOS Program for the Zonation (constrained Clustering) of Palaeoecological Data. ECRC UCL: London.

Juggins S. 2003. C2 Program. University of Newcastle.

Kobashi T, Severinghaus JP, Barnola J-M et al. 2010. Persistent multidecadal Greenland temperature fluctuation through the last millennium. Climatic Change 100: 733-756.

Kobashi T, Severinghaus JP, Brook EJ et al. 2007. Precise timing and characterization of abrupt climate change 8200 years ago from air trapped in polar ice. Quaternary Science Reviews 26: 1212-1222.

Lamb HH. 1965. The early medieval warm epoch and its sequel. Palaeogeography, Palaeoclimatology, Palaeoecology 1: 13-37.

Langdon PG, Holmes N, Caseldine CJ. 2008. Environmental controls on modern chironomid faunas from NW Iceland and implications for reconstructing climate change. Journal of Paleolimnology 40: 273-293.

Langdon PG, Ruiz Z, Brodersen KP et al. 2006. Assessing lake eutrophication using chironomids: understanding the nature of community response in different lake types. Freshwater Biology 51: 562-577.

Larocque I. 2008. Nouvelle fonction de transfert pour reconstruire la température à l'aide des chironomides préservés dans les sédiments lacustres. Institut national de la recherche scientifique, Centre Eau, Terre \& Environnement.

Larocque I, Grosjean M, Heiri O et al. 2009. Comparison between chironomid-inferred July temperatures and meteorological data ad 1850-2001 from varved Lake Silvaplana, Switzerland. Journal of Paleolimnology 41: 329-342.

Larocque I, Hall RI, Grahn E 2001. Chironomids as indicators of climate change: a 100-lake training set from a subarctic region of northern Sweden (Lapland). Journal of Paleolimnology 26: 307-322.

Larocque I, Pienitz R, Rolland N 2006. Factors influencing the distribution of chironomids in lakes distributed along a latitudinal gradient in northwestern Quebec, Canada. Canadian Journal of Fisheries and Aquatic Sciences 63: 1286-1297.

Larocque I, Rolland N, INRS-ETE. 2006. Le guide visuel des chironomides sub-fossils [i.e. sub-fossiles] du Québec à l'île d'Ellesmere. Institut national de la recherche scientifique, Eau, terre et environnement: Québec.

Larocque-Tobler I, Filipiak J, Tylmann W et al. 2015. Comparison between chironomid-inferred mean-August temperature from varved Lake Żabińskie (Poland) and instrumental data since 1896 ad. Quaternary Science Reviews 111: 35-50.

Larocque-Tobler I, Filipiak J, Tylmann W et al. 2016. Corrigendum to 'Comparison between chironomid-inferred mean-August temperature from varved Lake Zabinskie (Poland) and instrumental data since 1896 ad'. [Quat. Sci. Rev. 111 (2015) 35-50]. Quaternary Science Reviews 140: 163-167.

Larocque-Tobler I, Stewart MM, Quinlan R et al. 2012. A last millennium temperature reconstruction using chironomids preserved in sediments of anoxic Seebergsee (Switzerland): consensus at local, regional and Central European scales. Quaternary Science Reviews 41: 49-56.

Ljungqvist FC. 2010. A new reconstruction of temperature variability in the extra-tropical Northern Hemisphere during the last two millennia. Geografiska Annaler A 92: 339-351.

Lotter AF, Birks HJB, Hofmann W et al. 1997. Modern diatom, cladocera, chironomid, and chrysophyte cyst assemblages as quantitative indicators for the reconstruction of past environmental conditions in the Alps. I. Climate. Journal of Paleolimnology 18: 395-420.

Luoto TP, Nevalainen L. 2017. Quantifying climate changes of the Common Era for Finland. Climate Dynamics 49: 2557-2567.

Mann ME, Jones PD. 2003. Global surface temperatures over the past two millennia: global surface temperatures over the past two millennia. Geophysical Research Letters 30.

Mann ME, Zhang Z, Hughes MK et al. 2008. Proxy-based reconstructions of hemispheric and global surface temperature variations over the past two millennia. Proceedings of the National Academy of Sciences of the United States of America 105: 13252-13257.

Mann ME, Zhang Z, Rutherford S et al. 2009. Global signatures and dynamical origins of the Little Ice Age and Medieval Climate Anomaly. Science 326: 1256-1260.

Matthews JA, Briffa KR. 2005. The 'Little Ice Age': re-evaluation of an evolving concept. Geografiska Annaler: Series A, Physical Geography 87: 17-36.

Millet L, Arnaud F, Heiri O et al. 2009. Late-Holocene summer temperature reconstruction from chironomid assemblages of Lake Anterne, northern French Alps. The Holocene 19: 317-328.

Moberg A, Sonechkin DM, Holmgren K et al. 2005. Highly variable Northern Hemisphere temperatures reconstructed from low- and high-resolution proxy data. Nature 433: 613-617.

Naulier M, Savard MM, Bégin C et al. 2015. A millennial summer temperature reconstruction for northeastern Canada using oxygen isotopes in subfossil trees. Climate of the Past 11: 1153-1164.

Oliver DR, Roussel ME. 1983. The insects and arachnids of Canada. Part 11. The genera of larval midges of Canada. Diptera: Chironomidae. Minist. Supply Serv.

Orendt C. 1999. Chironomids as bioindicators in acidified streams: a contribution to the acidity tolerance of chironomid species with a classification in sensitivity classes. International Review of Hydrobiology 84: 439-449.

Overpeck JT, Webb T, Prentice IC. 1985. Quantitative interpretation of fossil pollen spectra: dissimilarity coefficients and the method of modern analogs. Quaternary Research 23: 87-108.

Payette S, Delwaide A. 2004. Dynamics of subarctic wetland forests over the past 1500 years. Ecological Monographs 74: 373-391.

Pinder LCV, Morley DJ. 1995. Chironomidae as indicators of water quality with a comparison of the chironomid faunas of a series of contrasting Cumbrian tarns. In Insects in a Changing Environment, Harrington R, Stork NE (eds). Academic Press: London; 272-293.

Reimer PJ, Bard E, Bayliss A et al. 2013. IntCal13 and Marine13 radiocarbon age calibration curves 0-50,000 years cal BP. Radiocarbon 55: 1869-1887.

Renssen H, Seppä H, Crosta X et al. 2012. Global characterization of the Holocene Thermal Maximum. Quaternary Science Reviews 48: 7-19.

Renssen H, Seppä H, Heiri O et al. 2009. The spatial and temporal complexity of the Holocene thermal maximum. Nature Geoscience 2: $411-414$

Rolland N, Larocque I, Francus P et al. 2009. Evidence for a warmer period during the 12th and 13th centuries ad from chironomid assemblages in Southampton Island, Nunavut, Canada. Quaternary Research 72: 27-37.

Rose C, Crumpton WG. 1996. Effects of emergent macrophytes on dissolved oxygen dynamics in a prairie pothole wetland. Wetlands 16: 495-502.

Saucier J-P., Grondin P, Robitaille A, et al. 2009. Écologie forestière. In Man. For. Seconde Édition Ouvrage Collect. Éditions MultiMondes Ordre Ing. For. Qué. Qué. 2: 165-315.

PAGES 2k Consortium. 2013. Continental-scale temperature variability during the past two millennia. Nature Geoscience 6: 339-346.

Thomas ER, Wolff EW, Mulvaney R et al. 2007. The 8.2 ka event from Greenland ice cores. Quaternary Science Reviews 26: 70-81.

Trachsel M, Grosjean M, Larocque-Tobler I et al. 2010. Quantitative summer temperature reconstruction derived from a combined biogenic si and chironomid record from varved sediments of Lake Silvaplana (south-eastern Swiss Alps) back to ad 1177. Quaternary Science Reviews 29: 2719-2730. 
Trachsel M, Kamenik C, Grosjean M et al. 2012. Multi-archive summer temperature reconstruction for the European Alps, ad 1053-1996. Quaternary Science Reviews, 46: 66-79.

Upiter LM, Vermaire JC, Patterson RT et al. 2014. Middle to Late Holocene chironomid-inferred July temperatures for the central Northwest Territories, Canada. Journal of Paleolimnology 52: 11-26.

Viau AE, Gajewski K. 2009. Reconstructing millennial-scale, regional paleoclimates of boreal Canada during the Holocene. Journal of Climate 22: 316-330.

Viau AE, Gajewski K, Sawada MC et al. 2006. Millennial-scale temperature variations in North America during the Holocene. Journal of Geophysical Research 111.
Viau AE, Ladd M, Gajewski K. 2012. The climate of North America during the past 2000years reconstructed from pollen data. Global and Planetary Change 84-85: 75-83.

Walker IR, Mathewes RW. 1987. Chironomids, lake trophic status, and climate. Quaternary Research 28: 431-437.

Walshe BM. 1950. The function of haemoglobin in Chironomus plumosus under natural conditions. Journal of Experimental Biology 27: 73-95.

Wiederholm T. 1983. Chironomidae of the Holarctic region: keys and diagnoses. Part 1: Larvae. Entomol Scandinavica. Supplement: 1-457.

Wright HE, Mann DH, Glaser PH. 1984. Piston corers for peat and Lake Sediments. Ecology 65: 657-659. 